\title{
IIIness Belief dan IIIness Representation pada Pasien Diabetes Mellitus: Study Phenomenologhy
}

\author{
Raudhotun Nisak ${ }^{1}$ Suhartini ${ }^{2}$ Niken Safitri D.K ${ }^{3}$ \\ ${ }^{1}$ Akademi Keperawatan Pemkab Ngawi \\ ${ }^{2,3}$ Prodi Magister Keperawatan Fakultas Kedokteran Universitas Diponegoro
}

Email: nisak.arif@gmail.com

\begin{abstract}
ABSTRAK
Latar Belakang: Diabetes Mellitus (DM) merupakan salah satu penyakit kronis yang membutuhkan strategi untuk dalam pengelolaan penyakitnya. Berbagai pengalaman dan pengetahuan pasien selama sakit dapat membentuk illness belief dan illness representation yang berbeda-beda pada pasien. Kesesuaian illness belief dan illness representation dapat menjadi salah satu kunci keberhasilan dalam pengelolaan penyakit ini. Tujuan: Studi ini merupakan studi pendahuluan yang bertujuan untuk mengetahui illness belief dan illness representation pada pasien DM. Metode: Metode dalam studi pendahuluan ini menggunakan design kualitatif dengan pendekatan phenomenology yang melibatkan sepuluh perawat dan sepuluh pasien di di Rumah Sakit Umum Daerah Dr. Soeroto Ngawi dan Rumah Sakit Widodo Ngawi. Pengambilan data dilakukan dengan indepth interview semistructure selanjutnya dianalisa menggunakan content analysis. Hasil: Tiga tema telah dididapatkan dalam studi ini, yaitu persepsi pasien tentang illness belief dan illness representation vs kelalaian pasien, persepsi perawat tentang illness belief dan illness representation vs tindakan mandiri perawat, serta dampak positif illness belief dan illness representation. Kesimpulan: Illness belief dan illness representation yang dimiliki oleh pasien DM memiliki pengaruh besar pasien DM. Tindakan perawat terkait dengan illness belief dan illness representation perlu ditingkatkan lagi sehingga dapat meningkatkan kesejahteraan pasien.
\end{abstract}

Keywords :

Illness belief, illness representation, diabetes mellitus

\section{PENDAHULUAN}

Diabetes Mellitus (DM) merupakan salah satu penyakit kronis yang ditandai oleh adanya peningkatan kadar gula darah dalam tubuh (hiperglikemia). Penyakit ini membutuhkan strategi untuk mengontrol gula darah pasien sehingga dapat mengurangi maupun mencegah komplikasi yang terjadi.
Berbagai komplikasi yang muncul dapat menjadi sumber penderitaan tersendiri bagi pasien maupun keluarganya (American Diabetes Association, 2016; World Health Organization-2016, 2016).

Prevalensi penderita DM semakin meningkat setiap tahun secara signifikan. Tahun 2013 jumlah penderita DM sebesar

\section{*Corresponding Author :}

Raudhotun Nisak

Akademi Keperawatan Pemkab

Email : nisak.arif@gmail.com 
382 juta orang (Guariguata et al., 2014), selanjutnya meningkat sebesar 415 juta pada 2015 dan diperkirakan semakin meningkat menjadi 642 juta pada tahun 2040, dimana jumlah penderita laki-laki menempati urutan teratas dibandingkan wanita dan anak-anak (International Diabetes Federation (IDF), 2015). Begitu tingginya angka kejadian penyakit ini, bahkan menjadi penyebab kematian terhadap 1,5 juta jiwa pada tahun 2012 (World Health Organization-2016, 2016), 5 juta jiwa pada tahun 2015 (Federation \& Alliance, 2016), dan diprediksi menjadi 7 penyebab kematian utama pada tahun 2030 (World Health Organization-2016, 2016).

Pasien DM sebagai individu dengan penyakit kronis mengalami banyak perubahan dalam dirinya. Hal ini menyebabkan pasien membutuhkan penyesuaian baik secara fisik yang melibatkan berkurangnya fungsi tubuh, maupun perubahan dalam rutinitas harian dalam rangka mengelola penyakitnya. Selama rentang waktu tersebut, berbagai pengalaman, pengetahuan, dan interaksi dengan orang lain dapat membentuk keyakinan terhadap penyakit (illness belief) (Årestedt, Benzein, \& Persson, 2015), serta representasi penyakit berdasarkan pemahaman pasien (illness representation) (Skinner et al., 2011). Illness belief dan illness representation pada masing-masing pasien ini dapat berubah, berkembang dan bebeda-beda sekalipun pada diagnosa yang sama (Årestedt et sal., 2015; Skinner et al., 2011).

\section{*Corresponding Author :}

Raudhotun Nisak

Akademi Keperawatan Pemkab

Email : nisak.arif@gmail.com
Sejumlah penelitian menunjukkan illness belief dan illness representation pada masing-masing pasien bervariasi, mulai dari keyakinan pasien terhadap psenyebab, lama sakit, pengaruh pengobatan, hingga keyakinan terhadap kemampuan diri mereka dalam mematuhi anjuran tim medis. Adanya illness belief dan illness representation yang berbedabeda ini dapat memberikan respon yang berbeda-beda pula pada pasien. Kerentanan pasien memiliki illness belief dan illness representation yang tidak sesuai dapat memberikan pengaruh negatif pada respon pasien. Oleh karena itu, adanya studi pendahuluan tentang illness belief dan illness representation pada pasien DM ini sangat diperlukan agar dapat dijadikan rujukan perawat dalam membantu pasien memilih perilaku yang tepat bagi mereka.

\section{METODE}

Metode yang digunakan dalam studi pendahuluan ini adalah studi kualitatif dengan pendekatan fenomenologi. Partisipan terdiri dari 10 pasien dan 10 perawat di Rumah Sakit Umum Dr. Soeroto Ngawi dan Rumah Sakit Widodo Ngawi. Adapun kriteria inklusi partisipan adalah pasien DM tipe 1 atau tipe 2 baik dengan komplikasi maupun tidak. Pengambilan data dilakukan dengan indepth interview semistructure berdasarkan pedoman wawancara dengan pertanyaan terbuka yang telah disusun peneliti. Hasil wawancara, selanjutnya dianalisa menggunakan content analysis berdasarkan rekomendasi dari Elo \& 
Kyngas (2008). Content analysis terdiri dari transcribing (membuat transkrip percakapan perawat dan pasien), menentuakan meaning unit untuk mencari hubungan antar kata, kalimat atau paragraf dan terakhir, melakukan abstraksi data hingga membentuk beberapa tema (Elo \& Kyngäs, 2008).

\section{HASIL}

Partisipan yang berpartisipasi dalam studi pendahuluan ini sebanyak 20 orang, yang terdiri dari 10 perawat dan 10 pasien. Partisipan perawat dengan jenis kelamin laki-laki sebanyak 3 orang, perempuan 7 orang, dan pendidikan terakhir mulai dari Diploma sampai Sarjana. Sedangkan partisipan pasien dengan jenis kelamin laki-laki sebanyak 2 orang, perempuan sebanyak 8 orang, menderita DM tipe 1 sebanyak 3 orang, DM tipe 2 sebanyak 7 orang, memiliki komplikasi sebanyak 3 orang, murni DM 7 orang, dan rentang usia antara 27-48 tahun. Tema-tema yang ditemukan dalam studi pendahuluan ini sebanyak tiga tema, dimana terdapat saling keterkaitan dan menggambarkan illness belief dan illness representation pada pasien DM. Berikut adalah penjelasan masing-masing tema yang diperoleh:

\section{Persepsi Perawat tentang IIIness Belief dan IIIness Representation vs Tindakan Mandiri Perawat}

Semua perawat mengungkapkan bahwa illness belief dan illness representation merupakan hal yang

penting dan menjadi bagian yang tidak bisa dipisahkan dalam manajemen

\section{*Corresponding Author :}

Raudhotun Nisak

Akademi Keperawatan Pemkab

Email : nisak.arif@gmail.com perawatan pasien DM. Selain itu, kedua hal tersebut juga harus diketahui oleh pasien maupun keluarganya. Hal tersebut tampak dalam pernyataan partisipan berikut:

"Misalnya pasien yakin jika penyakitnya memang penyakit kronis, yang sembuhnya lama. Terus bisa sembuh apa tidak, seperti itu. Nah, keyakinan semacam itu kan perlu sebenarnya buat mereka." $(\operatorname{Pr} 1)$

"Gejala, tanda, prognosis, komplikasi, diet, dII).....memang menjadi bagian dari manejeman perawatan pasien DM sehingga pasien harus tahu tentang hal tersebut." (Pr 2)

"Pasien harus tahu penyakitnya seperti apa. Misalnya, DM berasal dari pola makan yang salah. Maka dengan itu pasien menjadi tahu apa yang harus dia perbaiki pada pola makannya." (Pr 3)

"Selama pasien sakit itu harus punya keyakinan, istilahnya..apa ya...yakin bahwa saya akan sembuh atau jika tidak sembuh maka apa yang membuat saya bisa tetap sehat terus." (Pr 10)

"Pengetahuan tentang gejala, tanda, diet dan lainnya memang harus diketahui oleh pasien dan keluarga." (Pr 1)

Namun demikian, dalam kondisi di lapangan, persepsi yang dimiliki oleh 
perawat justru bertolak belakang dengan tindakan mandiri yang dilakukan perawat. Sebanyak tujuh dari sepuluh perawat menyatakan jika tindakan mereka terkait illness belief dan illness representation jarang dilakukan. Misalnya, mengkaji sejauh mana illness belief dan illness representation yang dimiliki pasien, khususnya saat pertama kali masuk pasien masuk di ruangan. Hal ini sebagaimana yang diungkapkan oleh perawat berikut ini :

"Tapi kalau sejauh ini, memang tidak pernah menanyakan tentang kepercayaan pasien terhadap penyakitnya secara khusus." ( $\operatorname{Pr} 1)$

Seorang perawat bahkan mengungkapkan jika ia tidak nyaman jika harus menanyakan illness belief pasien. Berikut pernyataannya:

"Secara spesifik tidak pernah sih, menanyakan terkait kepercayaan terkait penyakit pasien kok rasanya gimana gitu. Canggung ya kayaknya." (Pr 2)

Perawat menjelaskan bahwa fokus tindakan mereka selama ini adalah tindakan berdasarkan keluhan pasien secara fisik saja, seperti adanya luka gangren, pusing, dan nyeri. Berikut pernyataan partisipan:

"Lebih banyak memang kita sesuai dengan apa yang dikeluhkan pasien, misal ada luka, nyeri, perut kembung atau lainnya." $(\operatorname{Pr} 1)$

"Fokus kita biasanya lebih pada keluhannya, meskipun gula darah tinggi namun jika tidak merasakan keluhannya maka tidak pasien tidak apa-apa."(Pr 3)

"Namun secara umum untuk tindakan memang lebih cenderung pada keluhan secara fisik yang saat itu dikeluhkan pasien. Misalnya, ada luka gangrene, keluhan pusing atau lainnya."(Pr 4)

"Tindakan lain yang dilakukan berdasar keluhan fisik pasien, misalnya rawat luka jika terdapat luka setiap hari" $(\operatorname{Pr} 2)$

\section{Persepsi Pasien Vs Kelalaian Pasien terkait IIIness Belief dan IIIness Representation}

IIIness belief yang dimiliki oleh pasien terkait bahwa DM adalah penyakit yang dapat sembuh, DM adalah penyakit seumur hidup dan hanya bisa dikontrol serta keyakinan terhadap penyebab penyakit yang diderita saat ini. Sebanyak lima pasien menyatakan bahwa penyakit mereka dapat sembuh, meskipun membutuhkan waktu lama. Hal ini sebagaimana yang diungkapkan pasien dibawah ini :

"Penyakit saya ini memang sembuhnya lama."(Ps 1)

"Kudu yakin nek diparing mari masio suwe." (Ps 3)

"Saya harus punya keyakinan bisa sembuh mbak." (Ps 6)

\section{*Corresponding Author :}

Raudhotun Nisak

Akademi Keperawatan Pemkab

Email : nisak.arif@gmail.com 
"Setiap orang sakit itu harus yakin bisa sembuh mbak." (Ps 10)

"Kencing manis niku saget mantun, nanging dangu." (Ps 7)

Lima pasien lainnya menyatakan jika penyakit DM merupakan penyakit yang tidak dapat sembuh, tetapi hanya dapat dikendalikan dengan beberapa cara, seperti menjaga pola makan, minum obat teratur dan rutin periksa gula darah. Berikut ungkapan partisipan tersebut :

"Nek penyakite iki penyakit sing ga iso sembuh ning iso.....iso opo ya jenenge kae, dikendalikno." (Ps 4)

"Penyakit saya ini penyakit yang tidak bisa sembuh tapi bisa dikendalikan. Terus,caranya dengan mengurangi makanan dan minuman yang mengandung manis-manis, lalu obatnya diminum dengan teratur terus periksa juga" (Ps 9)

"Jadi ya yang saya yakini itu, ga bisa sembuh tapi bisa dikendalikan." (Ps 9)

"Penyakit sing selawase." (Ps 5)

"Penyakit selawase, dadi yo selawase ngombe obat terus." (Ps 5)

Pasien juga menambahkan jika keyakinan yang mereka miliki erat kaitannya dengan kemungkinan penyebab dari penyakit DM. Adanya kebiasaan mengkonsumsi makanan dan minuman manis serta riwayat keturunan DM yang dimiliki oleh anggota keluarga, diyakini menjadi penyabab penyakit ini. Berikut pernyataan partisipan terkait hal tersebut:

"Ngeten mbak, pancen kulo akui, yen kulo niku remenane sing legi-legi. Dados mpun kebiasaan istilahe, nek mboten kraos legi nggih mboten enak. Menawi niku sing dadi penyebabe sakit gulo niki." (Ps 8)

"Menawi penyebab e amargi remenane kulo kalih sing legi-legi, brarti kulo kedah ngurangi gendis. Ugo ngendikane pak dokter pas kulo pertama prikso, penyakit niki naming saget dikontrol, carane ngirangi sing manis-manis. Nggih sak liyane penyebabe gulo niku wau, penyakit niki penyakit keturunan. Soale ibuk kulo nggih sakit kados niki. Dadose nurun teng kulo." (Ps 8)

Pemahaman pasien terhadap penyakitnya (illness representation) telah gambarkan dalam empat hal, yaitu definisi, penyebab, gejala dan tindakan pengelolaan penyakit yang selama ini dilakukan oleh pasien. Hal tersebut dapat terlihat dari pernyataan di bawah ini :

"DM itu penyakit kencing manis, yang disebabkan karena keturunan bisa, makan yang manis-manis bisa." (Ps 6)

"Kalau pas badan itu terasa sakit semua berarti gula saya naik. Kalau sudah seperti itu saya periksa mbak, dan gula saya memang tinggi pas dicek." (Ps 1)

\section{*Corresponding Author :}

Raudhotun Nisak

Akademi Keperawatan Pemkab

Email : nisak.arif@gmail.com 
"Sudah kena penyakit gula mulai sekarang harus dijaga makannya, pake gula jagung apa itu...sing warnane kuning itu tho mbak bungkuse. Trus juga suruh sering cek gula darahnya." (Ps 2)

"Penyakit gulo, nggih kedah ngirangi sing legi-legi." (Ps 7)

Meskipun illness belief dan illness representation yang dimiliki pasien memperlihatkan adanya pemahaman terhadap penyakit mereka, namun pernyataan dari lima pasien dibawah ini menunjukkan adanya kondisi dilematis yang terjadi dalam diri mereka. Adanya keinginan untuk menghilangkan kebosanan akibat makanan atau minuman yang kurang berasa, membuat pasien terkadang sengaja makan atau minum yang mengandung gula tinggi kalori. Berikut pernyataan kelima partisipan tersebut:

"Tapi ya wong namanya manusia kadang kan pengen nyoba apa gitu mbak." (Ps 1)

"Yo sok-sok mbak, Iha wong sok nek pas ditukokne anakku ngunu yo nganggo. Yen pas entek, yo gulo biasa. Ben rodo' ana rasane." (Ps 3)

"Masio jane sok yo njajal sing ana rasane legi barang, Iha kabeh-kabeh kudu ditarak kan yo sok boden barang mbak." (Ps 4)

"Menawi maem e dijogo sakjane awake yo kepenak mbak. Lha ning sok-sok yo lali tur glali barang. Wong namine tiyang, nggih sok bosen, maem kraos kurang kroso. Sok nggih pengen sing ana rasa ne barang." (Ps 8)

"Awal-awal pernah mbak karena mungkin bosan dengan makanan yang kurang mantep, ngga kayak biasanya kan, tak tambah sedikit gulanya. Eh, malamnya langsung badan rasanya pegel-pegel, waktu tak diperiksa ternyata naik lagi gulanya." (Ps 10)

\section{Dampak Positif Illness Belief dan IIIness Representation}

Baik pasien maupun perawat mengungkapkan bahwa illness belief dan illness representation berpengaruh bagi pasien. Dampak tersebut meliputi dampak psikologis, dampak fisiologis dan dampak terhadap perilaku. Dampak psikologis dirasakan dengan meningkatnya motivasi pasien dalam menjaga kesehatan mereka. Tidak hanya pasien, perawat juga merasakan bahwa meningkatkanya motivasi ini, pasien menjadi lebih kooperatif terhadap tindakan yang diberikan perawat selama di rumah sakit. Sebagaimana pernyataan partisipan dibawah ini:

"(IIIness belief dan illness representation) Besar sekali pengaruhnya, sebab dengan tahu penyakitnya maka kita harapkan pasien menjadi termotivasi semangatnya dan akhirnya kooperatif dalam proses perawatannya selama di rumah sakit." (Pr 4)

\section{*Corresponding Author :}

Raudhotun Nisak

Akademi Keperawatan Pemkab

Email : nisak.arif@gmail.com 
"Jelas berpengaruh sekali. Ya itu tadi...sebab keduanya menyebabkan pasien menjadi termotivasi, terus lebih menjaga kesehatannya. Kalau pasien DM, misalnya menjaga dietnya." (Pr 10)

"Penting mbak. Ya tadi...saya jadi termotivasi istilahnya. Kan juga pengen hidup sehat seperti orangorang lainnya." (Ps 6)

"Saya jadi bisa wanti-wanti diri mbak. Jaga dirilah istilahnya. Mana yang harus dikurangi, mana yang boleh dimakan." (Ps 6)

Beberapa kondisi fisik pasien sebagai dampak secara tidak langsunng adanya illness belief dan illness representation juga ditunjukkan dalam hasil studi pendahuluan ini. Berikut pernyataan yang mendukung hal tersebut:

"Pengaruhe yo kudu ngati-ngati kuwi mau mbak ben ga gampang kesel awake." (Ps 1)

"Jadinya badan itu terasa lebih enak. Tidak gampang capek, lemes." (Ps 6)

"Lha nggih kersane kepenak to awake. Yen biasane sok nggliyer, nek kumat ngoten awak niku rasane sakit sedoyo mbak. Nggih, istilahe kesehatane kan tambah apik." (Ps 7)

"Dua hari dirawat kemudian pasien mau mobilisasi hari ketiga keempat sudah membaik, sekalipun dia punya luka." (Pr 9)
"(IIlness belief dan illness representation) Berpengaruh. Misalnya pasien tahu kalau GDA-tidak stabil maka yang terjadi pasien lemes, keringat dingin, bahkan ada yang sampai gelisah atau tidak sadar." ( $P r$ 7)

Sedangkan dari segi perilaku pasien, illness belief dan illness representation memberikan pengaruh dampak positif. Beberapa perilaku pasien seperti lebih menjaga pola makan, kontro rutin dan periksa menjadi perilaku yang nyata dilakukan pasien. berikut pernyataan partisipan :

"Jelas sangat penting dan berpengaruh ya mbak. Kan dengan pasien yakin dan tahu tentang seluk beluk penyakitnya lalu jadi kooperatif saat di rawat." $(\operatorname{Pr} 6)$

"Hmm...misalnya ya, pasien yang motivasinya bagus lalu mematuhi apa yang disampaikan perawat maka biasanya yang kita temukan itu dia membaik kondisinya." (Pr 8)

"Pokoke saya dadi kudu ngati-ngati lah mbak sama makannya karena kan dokter e dah bilang gitu." (Ps 1)

"Penting mbak, kan nek ngerti dadi bisa diati-ati dewe maeme sing bener piye." (Ps 1)

"Ya masio mungkin sembuhnya lama tapi kan tetap harus semangatlah mbak. Kasihan masih ada anak, cucu jadi bisa terus semangat masio harus

\section{*Corresponding Author :}

Raudhotun Nisak

Akademi Keperawatan Pemkab

Email : nisak.arif@gmail.com 
sering ke dokter ato minum obat." (Ps 2)

\section{PEMBAHASAN}

\section{Persepsi Perawat Vs Tindakan Mandiri Perawat terkait IIIness Belief dan IIIness Representation}

Persepsi perawat yang didapatkan dalam studi pendahuluan ini menunjukkan bahwa illness belief dan illness representation merupakan hal penting dan menjadi bagian yang tidak bisa dipisahkan dari manejemen perawatan pasien DM. Urgensi illness belief dan illness representation yang dirasakan perawat dikaitkan dengan respon maupun tindakan yang akan dipilih atau digunakan oleh pasien dalam mengelola penyakit mereka. Hasil ini juga memperlihatkan bahwa perawat sebagai bagian dari tenaga kesehatan menyadari peran mereka dalam membantu pasien untuk memperbaiki status kesehatan mereka.

Peran tenaga kesehatan juga telah disebutkan dalam hasil penelitian Franks et al (2006) yang memperlihatkan adanya keterkaitan antara peran perawat dengan sejumlah sejumlah outcome pada kesehatan pasien (Franks et al., 2006). Pentingnya illness representation pada pasien juga ditunjukkan pada hasil penelitian Sultan et al (2011). Hasil tersebut juga memperlihatkan bahwa illness representation yang dimiliki pasien berhubungan dengan perilaku self care pasien mereka (Sultan, Attali, Gilberg, Zenasni, \& Hartemann, 2011). Hal ini semakin membuktikan bahwa persepsi yang dimiliki oleh perawat dapat menjadi kunci keberhasilan pasien dalam memperbaiki perilaku hingga menyebabkan sejumlah outcome bagi kesehatan mereka.

Namun demikian, persepsi tersebut kontras dengan pengakuan perawat terkait tindakan mandiri illness belief dan illness representation selama ini. Sebanyak enam perawat menyatakan tidak pernah menanyakan bagaimana illness belief dan illness representation pasien, sebaliknya perawat baru akan menjawab apabila pasien bertanya terkait penyakit mereka. Selain itu, pasien DM yang sering keluar masuk rumah sakit menjadi alasan perawat untuk tidak menanyakannya.

Temuan ini bertolak belakang dengan pendapat yang menyebutkan jika illness belief dan illness representation yang dimiliki pasien akan berubah seiring dengan pengalaman dan pengetahuan yang mereka dapatkan selama sakit (Adair-Stantiall, 2011; Santos, Hurtadoortiz, \& Sneed, 2016). Perubahan ini hendaknya dapat diidentifikasi oleh perawat sehingga dapat memberikan intervensi yang tepat pada pasien.

Adanya pengakuan perawat tentang belum pernah adanya kajian khusus terkait illness belief dan illness representation di rumah sakit mereka dimungkinkan menjadi salah satu penyebab perawat tidak pernah menanyakan illness belief dan illness representation pasien selama ini. Adanya rekomendasi terkait kajian illness belief dan illness representation di rumah sakit

\section{*Corresponding Author :}

Raudhotun Nisak

Akademi Keperawatan Pemkab

Email : nisak.arif@gmail.com 
mungkin diperlukan untuk peningkatan asuhan keperawatan.

\section{Persepsi Pasien Vs Kelalaian Pasien terkait IIIness Belief dan IIIness Representation}

Persepsi pasien tentang illness belief yang mereka miliki bervariasi, mulai dari keyakinan bahwa penyakit mereka bisa atau tidak bisa sembuh, penyebab, hingga cara pengelolaan penyakit. Secara umum, persepsi pasien telah sesuai dengan konsep penyakit DM, hanya saja sebagian pasien masih memiliki pemahaman jika penyakit DM dapat sembuh meskipun membutuhkan waktu lama.

IDF (2015) menyebutkan bahwa pada dasarnya penyakit DM tidak dapat disembuhkan, melainkan hanya dapat dikendalikan dengan mengontrol gula darahnya. Adanya belief pasien bahwa DM dapat disembuhkan, dapat menimbulkan sebuah harapan baru bagi pasien. Namun demikian, ketidaksesuaian belief ini, justru dapat menurunkan motivasi pasien jika pasien terlambat mengetahui bahwa penyakitnya hanya bisa dikendalikan saja. Oleh karena itu, peran perawat dalam mengidentifikasi illness belief pasien sangat diperlukan dalam pengelolaan pasien DM.

Studi ini juga menemukan bahwa apa yang dialami pasien saat ini memberikan kekhawatiran tersendiri bagi mereka. Perasaan takut dan khawatir akan kondisi mereka akibat penyakit DM serta ketidakmampuan dalam menjalankan aktivitas sehari-hari dipercaya pasien menjadi ancaman dalam kehidupan mereka. Meski demikian, pasien juga menyatakan bahwa adanya keluarga yang menemani dan membantu, terutama saat mereka sakit dapat meringankan beban dan memberikan support tersendiri Hal ini menunjukkan bahwa peran keluarga memiliki peran besar saat ada keluarga yang sakit.

Secara spesifik,

Keterkaitan antara belief pasien, peran keluarga dan perawat (tenaga kesehatan) ini sebagaimana hasil penelitian Arestedt et al (2015). Penelitian yang mengacu pada konsep IIIness Belief Model (IBM) oleh Wright \& Bell (2009) tersebut, menjelaskan bahwa IBM mencakup bagaimana individu dan keluarga memandang sakit sebagai bagian dan ancaman dalam kehidupan, keluarga menjadi bagian yang penting saat sakit, serta harapan terhadap pelayanan kesehatan yang mereka datangi (Årestedt et al., 2015). Ketiganya memiliki porsi yang sama dalam membentuk belief yang diyakini oleh pasien.

Illness Belief Model (IBM) juga menjelaskan bahwa pasien dengan penyakit kronis, harus membuat pola hidup baru dalam kegiatan sehari-hari yang disesuaikan dengan kebutuhan anggota keluarga yang sakit. Sehingga berbagai perubahan yang timbul pada pada pasien DM tidak hanya berpengaruh pada diri pasien saja, namun juga keluarganya. Adanya keyakinan yang dimiliki oleh anggota keluarga terhadap pasien dan penyakitnya dapat mempengaruhi kemampuan keluarga

\section{*Corresponding Author :}

Raudhotun Nisak

Akademi Keperawatan Pemkab

Email : nisak.arif@gmail.com 


\section{dalam melakukan pemeliharaan} kesehatan pasien.

Oleh karena itu, keluarga juga membutuhkan bantuan dan dukungan dari tenaga kesehatan dalam menentukan strategi yang paling tepat untuk meningkatkan kesejahteraan dan kesehatan keluarga. Namun pada studi ini, keluarga pasien tidak dilakukan wawancara sehingga pandangan tentang illness belief hanya bersumber dari pasien saja.

Sedangkan illness representation yang ditemukan dalam studi pendahuluan ini mengggambarkan empat hal, yaitu definisi, penyebab, gejala, tindakan pengelolaan penyakit serta respon emosional yang dirasakan pasien. Hal ini sesuai dengan konsep Common Sense Self Regulatory Model of Representation diperkenalkan oleh Leventhal (1984). Konsep ini menggambarkan individual belief's dan perilaku kesehatannya yang terbagi dalam cognitif representation dan emotional representation sehingga terdiri dari beberapa dimensi, yaitu identitas, penyebab, durasi, konsekuensi, kontrol dan emosional (Petrie, Jago, \& Devcich, 2007). Berdasarkan konsep in pula, dapat dipahami bahwa illness representation yang dimiliki oleh seorang pasien, dapat memberikan motivasi bagi dirinya sendiri sehingga mampu berperilaku positif dalam mengelola penyakitnya dan membangun kembali kesehatannya.

Meskipun illness belief dan illness representation yang dimiliki pasien memperlihatkan adanya pemahaman terhadap penyakit mereka, namun pernyataan dari sebagian pasien menunjukkan adanya kondisi dilematis yang terjadi dalam diri mereka. Adanya kebosanan atas apa yang mereka konsumsi selama ini membuat pasien terkadang sengaja makan atau minum yang mengandung gula tinggi kalori. Hal ini menunjukkan bahwa tidak mudah bagi sebagian pasien untuk beradaptasi dengan perubahan yang dialami saat ini. Sehingga diperlukan bantuan perawat dalam menumbuhkan motivasi pasien sehingga pasien dapat beradaptasi dengan baik.

\section{Dampak Positif Illness Belief dan IIIness Representation}

Studi pendahuluan ini juga menemukan jika illness belief dan illness representation memiliki pengaruh besar bagi pasien. Pengaruh ini tidak hanya dari segi psikologis saja, namun juga terhadap perilaku dan fisiologis pasien. Berdasarkan pernyataan partisipan, dapat disimpulkan jika motivasi yang tercipta akibat illness belief dan illness representation yang dimiliki pasien, dapat menyebabkan perubahan perilaku hingga perubahan fisiologis dalam diri mereka. Hal ini juga menunjukkan bahwa antara illness belief dan illness representation, motivasi, perilaku serta perubahan fisiologis pasien mempunyai hubungan yang erat.

Dampak illness belief dan illness representation ini sesuai dengan beberapa hasil penelitian, diantaranya Sweileh et al (2014) yang membuktikan bahwa belief pasien DM tipe 2 mempunyai hasil yang signifikan dengan kepatuhan pengobatan pasien. Begitu

\section{*Corresponding Author :}

Raudhotun Nisak

Akademi Keperawatan Pemkab

Email : nisak.arif@gmail.com 
pula illness representation yang terbukti dapat meningkatkan kepatuhan dan self care pasien (McGrady, Peugh, \& Hood, 2014; Nouwen, Law, Hussain, \& Mcgovern, 2009) dan menentukan koping yang digunakan oleh individu (AdairStantiall, 2011).

Selain itu, dengan meningkatnya kepatuhan pasien terhadap anjuran tenaga kesehatan, illness belief dan illness representation secara tidak langsung juga dapat mempengaruhi kualitas hidup pasien. Sebagaiamana penelitian Perwitasari \& Urbayatun (2016) bahwa pasien dengan tingkat kepatuhan yang tinggi terhadap pengobatan berhubungan dengan tingginya kualitas hidup pasien DM. Begitupula, Rantung et al (2015) dan Rahayu (2016) juga menunjukkan bahwa semakin tinggi perilaku self care pasien maka semakin tinggi pula kualitas hidup mereka, begitupula sebaliknya.(Rahayu, 2016; Rantung, Yetti, \& Herawati, 2015). Berdasarkan hal tersebut, maka illness belief dan illness representation terbukti mempunyai dampak positif bagi pasien.

\section{KESIMPULAN}

Studi pendahuluan ini menghasilkan tiga tema, dimana semua tema tersebut memiliki keterkaitan yang menunjukkan pentingnya illness belief dan illness representation bagi pasien DM. Ilness belief dan illness representation yang dimiliki pasien juga memperlihatkan adanya pengaruh terhadap kemampuan pasien dalam menentukan perilaku mereka saat sakit. Adanya perbaikan kondisi pasien dapat

\section{*Corresponding Author :}

Raudhotun Nisak

Akademi Keperawatan Pemkab

Email : nisak.arif@gmail.com menjadi cerminan adanya perilaku positif yang mereka pilih. Perawat dapat membantu pasien dalam mengoptimalkan pengkajian terkait illness belief dan illness representation sehingga dapat membantu pasien dalam menentukan tindakan yang tepat bagi diri mereka sendiri.

\section{KETERBATASAN DAN REKOMENDASI PENELITIAN SELANJUTNYA}

Studi pendahuluan ini memiliki beberapa keterbatasan penelitian, diantaranya proses wawancara dilakukan pada beberapa pasien dan perawat dalam ruangan rawat inap yang sama. Hal ini dapat menimbulkan adanya bias dalam hasil wawancara karena antar partisipan masih dapat saling mendengar pertanyaan peneliti maupun jawaban dari partisipan yang lain. Selain itu, adanya kendala bahasa yang dimiliki pasien untuk memahami bahasa Indonesia membuat peneliti harus mengulang-ulang pertanyaan selama proses wawancara. Namun terlepas dari keterbatasan tersebut, hasil studi penelitian ini telah dapat memberikan gambaran akan pentingnya illness belief dan illness representation yang tidak hanya bagi pasien DM, namun juga perawat di rumah sakit. Adapun rekomendasi terhadap penelitian selanjutnya terkait dengan faktor manakah yang paling dominan antara illness belief dan illness representation dalam meningkatkan kualitas hidup pasien. 


\section{DAFTAR PUSTAKA}

Adair-Stantiall, A. (2011). Illness Representations, Coping and Psychosocial Outcome in Chronic Pain. Proc. Int. Joint Conf. Biometrics.

American Diabetes Association. (2016). Standards of Medical Care in Diabetes - 2016. Diabetes Care, 39(1). https://doi.org/10.2337/dc14S014

Årestedt, L., Benzein, E., \& Persson, C. (2015). Families living with chronic illness: beliefs about illness, family, and health care. Journal of Family Nursing, 21(2), 206-231. https://doi.org/10.1177/10748407155 76794

Elo, S., \& Kyngäs, H. (2008). The qualitative content analysis process. Journal of Advanced Nursing, 62(1), 107-115.

https://doi.org/10.1111/j.13652648.2007.04569.x

Federation, I. D., \& Alliance, I. (2016). Diabetes and Ramadan: Practical Guidelines.

Franks, P., F Jerant, A., Fiscella, K., G Shields, C., J Tancredi, D., \& $M$ Epstein, R. (2006). Studying physician effects on patient outcomes: Physician interactional style and performance on quality of care indicators. Social Science and Medicine, 62(2), 422-432. https://doi.org/10.1016/j.socscimed.2 005.05.027

Guariguata, L., Whiting, D. R., Hambleton, I., Beagley, J.,

\section{*Corresponding Author :}

Raudhotun Nisak

Akademi Keperawatan Pemkab

Email : nisak.arif@gmail.com
Linnenkamp, U., \& Shaw, J. E. (2014).

Global estimates of diabetes prevalence for 2013 and projections for 2035. Diabetes Research and Clinical Practice, 103(2), 137-149. https://doi.org/10.1016/j.diabres.201 3.11 .002

Hemphill, R. C., Stephens, M. A. P., Rook, K. S., Franks, M. M., \& Salem, J. K. (2013). Older Adults' Beliefs about The Timeline of Type 2 Diabetes and Adherence to Dietary Regimens. Psychology \& Health, 28(2), 139-53. https://doi.org/10.1080/08870446.20 12.685740

International Diabetes Federation (IDF). (2015). Diabetes Atlas Seventh Edition. IDF.

McGrady, M. E., Peugh, J. L., \& Hood, K. K. (2014). Illness representations predict adherence in adolescents and young adults with type 1 diabetes. Psychol Health, 29(9), 985-998.

https://doi.org/10.1080/08870446.20 14.899361

Nouwen, A., Law, G. U., Hussain, S., \& Mcgovern, S. (2009). Comparison of The Role of Self-Efficacy and IIIness Rrepresentations in Relation to Dietary Self-Care and Diabetes Distress in Adolescents with Type 1 Diabetes, 24(9), 1071-1084. https://doi.org/10.1080/08870440802 254597

Patel, N. R., Chew-Graham, C., Bundy, C., Kennedy, A., Blickem, C., \& Reeves, D. (2015). Illness Beliefs and the Sociocultural Context of 
Simpson, J., Lekwuwa, G., \& Crawford, T.

Diabetes Self-Management in British South Asians: a Mixed Methods Study. BMC Family Practice, 16, 58. https://doi.org/10.1186/s12875-0150269-y

Petrie, K., Jago, L. a, \& Devcich, D. a. (2007). The role of illness perceptions in patients with medical conditions. Current Opinion in Psychiatry, 20(2), 163-167. https://doi.org/10.1097/YCO.0b013e $328014 \mathrm{a} 871$

Rahayu, N. S. (2016). Hubungan Perilaku Perawatan Diri dengan Kualitas Hidup Penderita Diabetes Melitus Tipe 2 di Poliklinik Khusus Penyakit Dalam RSUP. DR. M/ Djamil Padang. Fakultas Keperawatan Universitas Andalas Padang, 51, 2015-2016.

Rantung, J., Yetti, K., \& Herawati, T. (2015). Hubungan self-care dengan kualitas hidup pasien diabetes melitus (DM) di Persatuan Diabetes Indonesia (Persadia) cabang Cimahi. Jurnal Skolastik Keperawatan, 1(1), 38-51.

Santos, S. J., Hurtado-ortiz, M. T., \& Sneed, C. D. (2016). Illness Beliefs Regarding the Causes Diabetes Among Latino College Students, 8156, 395-412. https://doi.org/10.1177/07399863093 39911

Sicree, B. R., Shaw, J., \& Zimmet, P. (2012). The Global Burden Diabetes and Impaired Glucose Tolerance. IDF Diabetes Atlas, 1-105. https://doi.org/10.1097/01.hjr.000036 8191.86614.5a

\section{*Corresponding Author :}

Raudhotun Nisak

Akademi Keperawatan Pemkab

Email : nisak.arif@gmail.com
(2013). Illness beliefs and psychological outcome in people with Parkinson's disease. Chronic Illness, 9(2), 165-76. https://doi.org/10.1177/17423953134 78219

Skinner, T. C., Carey, M. E., Cradock, S., Dallosso, H. M., Daly, H., Davies, M. J., ... Oliver, L. (2011). Comparison of Illness Representations dimensions and Illness Representation Clusters in Predicting Outcomes in The First Year following Diagnosis of Type 2 Diabetes: Results from the DESMOND trial. Psychology \& Health, 26(3), 321-35. https://doi.org/10.1080/08870440903 411039

Sultan, S., Attali, C., Gilberg, S., Zenasni, F., \& Hartemann, A. (2011). Physicians' Understanding of Patients' Personal Representations of Their Diabetes: Accuracy and Association with Self-Care. Psychology \& Health, 26 Suppl 1(April 2013), 101-17. https://doi.org/10.1080/08870441003 703226

World Health Organization-2016. (2016). Global Report on Diabetes. ISBN, 39, 88. https://doi.org/ISBN 978924 1565257 
Jurnal Medika Karya IImiah Kesehatan

Vol 5, No.1. 2020

ISSN : 2654-945X (Online), 2541-4615 (Print)

Journal homepage : http://jurnal.itkeswhs.ac.id/index.php/medika

*Corresponding Author :

Raudhotun Nisak

Akademi Keperawatan Pemkab

Email : nisak.arif@gmail.com 